\title{
The environmental education strategy of integration of universities, NGOs and elementary schools to develop Taiwan's energy education program
}

\author{
C.-K. Ku ${ }^{1}$, Y.-W. Chen ${ }^{2}$, T.-S. Kao ${ }^{3}$ \& S.-C. Chien ${ }^{3}$ \\ ${ }^{I}$ Department of Natural Science, \\ Taipei Municipal University of Education, Taiwan \\ ${ }^{2}$ CarbonZero Too, Co., Ltd., Taiwan \\ ${ }^{3}$ Graduate School of Environmental Education and Resources, \\ Taipei Municipal University of Education, Taiwan
}

\begin{abstract}
This research aims at constructing an Energy School in collaboration with local corporate-type NGOs (Delta Electronics Foundation), Taipei Municipal University of Education (TMUE) and elementary schools which engage in energy education programs in Taiwan. The content and strategy of Taiwan's energy education program (TEEP) includes developing specifically sustainable/low carbon campus indicators for self-evaluation, school-based curriculums, and teachers' training or empowerment. TMUE plays the role of integrating the curriculum experts, professors and school teachers, editing new teaching materials and developing self-evaluation indicators for participant schools, called energy school. The Delta Electronics Foundation provides funding and relevant expertise. Five aspects of self-evaluation in TEEP are compiled into a questionnaire, through the Fuzzy Delphi method. Self-evaluation Indicators for an Energy School to promote a whole-school approach energy education is an efficient strategy to bring environmental sustainable ability into Taiwan's elementary schools. Taiwan's Ministry of Education recognizes it is an outstanding model and requests these schools to help to promote TEEP to other schools.
\end{abstract}

Keywords: whole-school approach, Taiwan's energy education program, self-evaluation indicators for energy school. 


\section{Introduction}

The implementation of energy schools should not only achieve the goal of energy efficiency and carbon reduction, but should be promoted in a sustainable way at schools. Besides the instalment and improvement of hardware, problems like how to implement school policy, how to design lesson plans related to energy issues, how to bring changes to teachers, students and households, and how to cope with the ever changing environmental issue, should be addressed. Through the creation of self-evaluation indicators, energy schools could have references and the criteria of self-evaluation in planning structures of administration, teaching, living, software and hardware.

\subsection{Energy School self-evaluation indicators}

The research aims at creating self-evaluation indicators of establishing Taiwan Energy School. Fien et al. [1] points out that to promote environment education, whole-school approach should be applied. In Taiwan there are some of literature review of related environment education evaluation indicators: Tang [2], Gough [3], Wang [4], Yu and Zhang [5], Gao and Gao [6], Zhang [7] and Lu [8], Green School [9-11]. We also analyze related environmental education evaluation indicators, literature review of case study and related indicators, exploring evaluation indicators and observation of energy campus in New Taipei City, in order to construct the fundamental concept of the research.

\subsubsection{Eco-school}

The principles of eco-schools in Britain are an implementation of environmental education and a sustainable campus, through actions of environmental protection and remodelling a campus, an ecological campus is established. The factors of evaluation to promote energy schools comprised of energy, garbage, reduction of waste, water resource, transportation, healthy living, biodiversity, schools and global perspective.

The framework of implementation is constructed through the following factors [12]: ecological committee, ecological audit, action plans, monitor actions and evaluation, curriculum integration, the involvement of schools and communities and ecological rules.

\subsubsection{Sustainable campus}

Henderson and Tilbury [13] point out that the management of the whole-school approach is the practical teaching solution of promoting sustainable development education, twelve key points which can successfully promote sustainable campus' are as follows: actions of whole-school approach and improvement projects, mutually beneficial communities, involvement of learning process, incorporating environmental education, sustainable education into the curriculum, and more. 


\subsection{Teaching materials}

US Wisconsin K-12 Energy Education Program (KEEP) adopts energy efficiency manuals to implement campus energy management, besides emphasizing cost reduction and energy efficiency. Energy management is not limited to a limited number of people, but each should have its own responsibility to help monitoring $[14,15]$.

\subsection{Social responsibility of enterprises}

The involvement of corporates in public warfare is a way of fulfilling social responsibility. The inner motivation of involving public welfare work according to priority: facilitate enterprise's public-image and public relationship, gain recognition from communities and society; the outer motivations carry out social responsibility. Ways of public warfare include: assistance and support from corporate volunteers, financial sponsorship.

\section{Methods}

This framework based on literature review of related environment education evaluation indicators concludes five aspects of implementing environment education: policy and management, architecture and facilities, curriculum and teaching, living and behaviour, and training and empowerment. On the basis of these aspects, and assisted by case studies of schools which employed a wholeschool approach, evaluation of related Energy Schools, sustainable campus, low carbon schools, the self-evaluation indicators for Energy School is thus outlined. According to this outline, a set of questionnaires based on Fuzzy Delphi is compiled and created.

\subsection{Self-evaluation indicators for energy school}

This study primarily analyzed related literature, secondly employed Fuzzy Delphi and Analytic Hierarchy Process to compile scholars' opinion on selfevaluation indicators for Energy schools. A total of 12 scholars are from different expertise areas such as education, architecture, environment, sustainable environment, curriculum and teaching, living and behaviour and school principals who have experience of promoting sustainable campus, energy schools and low carbon schools. The questionnaire is divided into two categories according to the expertise of scholars and experts: "energy school" and "establishing indicators", and carried out in two stages. The evaluation indicators for energy schools are outlined according to the following five aspects: 1. policy and management, 2. architecture and facility, 3. curriculum and teaching, 4. living and behaviour, and 5. training and empowerment. These are the first level of indicators, and underneath is the second level of indicators, then a third level of indicators, serving the main framework of this research (Figure 1). 


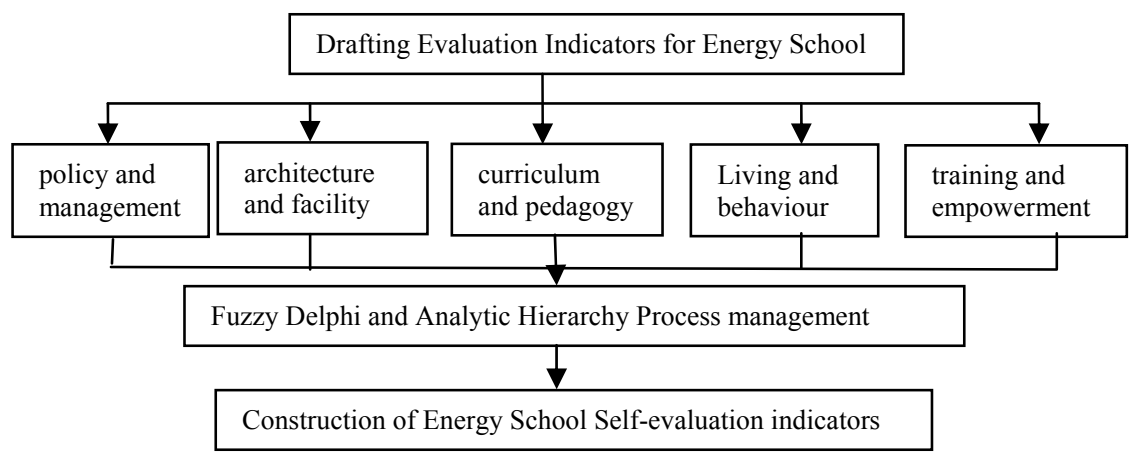

Figure 1: $\quad$ Process for establishing self-evaluation indicators for energy school.

\subsection{Editing teaching materials of TEEP}

The teaching materials of TEEP are developed based on the process of Analysis, Design, Development, Implementation and Evaluation (ADDIE) as shown below:

Demand for evaluation: Understand teachers' need through seminars, and figure out which knowledge, skill and attitude that teachers require in the process of teaching.

Analyze: Working items mainly include learners, learning environment, resource available and teaching media.

Design: Working items include pedagogical goals, framework design, learning strategy and pedagogical material prototype.

Development: In this stage, major tasks are writing and developing teaching materials.

Implementation: Editing and finalizing teaching files.

Evaluation: Evaluation aims at teaching materials. At this stage, the teaching material will be tested in real classrooms to examine the design quality of the teaching material. Opinions from learners, designers of teaching materials, content experts will be gathered and revised after discussions.

\subsection{Incorporate energy volunteer teachers and informal teaching materials from corporate employee and community}

Corporate volunteers undergo teacher training in order to serve students experience class for informal education. On the one hand, energy education is promoted, and on the other hand, understanding the status and demand of basic teaching status. Five energy schools selected in this project will have the priority to experience the lessons, in order to gather enough experience and feedback to enhance the production of TEEP. These teaching materials will be promoted to corporate and NGO volunteers, and organize ten seminars, and there are 250 
volunteer teachers selected as research participants. Under informal teaching materials of TEEP, eight lessons are created for energy volunteer teachers to teach at K-12. Four lessons are related to energy conservation and the other four lessons are concern about low-carbon issues.

Corporate volunteers are trained as energy teachers. From the year of 2009 to 2010, 374 energy volunteer teachers participated in TEEP and served at 270 classes and 98 schools. Approximately 11,836 students and their families gained benefits from this energy education program. The design of the questionnaire included teachers' background and satisfied factors. The Likert scale is used to explore teachers from different background. There were a total of 161 questionnaires in 2010.

\section{Results and discussion}

\subsection{Self-evaluation indicators for energy school}

The indicators are compiled based on the results of a questionnaire which is designed in two stages, Fuzzy Delphi method and Analytic Hierarchy Process, after the analysis of related environmental education indicators and evaluations. These indicators are conducted in five particular elementary schools which engaged in the whole-school approach energy school project. Taiwan's Ministry of Education recognizes the significant role of these energy schools, and requests these schools to set up energy education centers to help promote TEEP to their regions. The indicators are elaborated as follows, see Table 1.

Table 1: $\quad$ Energy School self-evaluation indicators.

\begin{tabular}{|l|}
\hline Energy School self-evaluation Indicators \\
\hline 1. Policy and management \\
\hline 1-1 reaching consensus \\
\hline 1-1-1 Understand the importance of energy issues and energy saving. \\
1-1-2 Support and commitment of school principles. \\
1-1-3 Shaping teachers and student's conviction and vision of energy education. \\
\hline 1-2 Environment survey \\
\hline 1-2-1 Conduct surveys on energy consuming status. \\
1-2-2 Conduct surveys on green cover ratio. \\
\hline 1-3 Environment survey \\
1-3-1Develop Energy efficient Program which focuses on school-based curriculum, \\
1-3-3 Set up short term, middle term and long term plans on energy saving and carbon \\
reduction. \\
1-3-4 Regulate policy of prohibiting usage of disposable tableware. \\
1-3-5 Establishing feedback mechanism to organize energy saving competition. \\
1-3-6 Give rewards to teachers who design and implement energy education classes. \\
\hline 1-4 Energy Management Plan out electricity resource strategy \\
\hline $\begin{array}{l}\text { 1-4-1 Examine reasonable volume stated in the contract regularly. } \\
\text { 1-4-3 Onnual energy use intensity (EUI) ( } \mathrm{kWh} / \mathrm{m}^{2} \cdot \mathrm{yr} \text { ) smaller or equals to } 18.6 .\end{array}$ \\
\hline
\end{tabular}




\begin{tabular}{|c|}
\hline 1-5 Energy Management $\sim$ Plan out water resource strategy \\
\hline $\begin{array}{l}\text { 1-5-1 Water consumption for everyone, less or equals to } 18 \text { litre. } \\
\text { 1-5-2 Enhance water resource efficiency, in order to save } 20 \% \text { comparing to the last } \\
\text { period. } \\
\text { 1-5-3 Enhance recycle rate of rain water and other usage of water. } \\
\text { 1-5-4 High efficiency of watering facilities and cutting grass in moderate scale. } \\
\text { 1-5-5 Rate of water resource utilization should be } 4 \% \text { more than total water utilization. }\end{array}$ \\
\hline 1-6 Energy Management Enhance permeable surface of campus. \\
\hline $\begin{array}{l}\text { 1-6-1 Reduce chemical pesticide and herbicide to maintain and manage green field in } \\
\text { campus. } \\
\text { 1-6-2 Growing native species of plants which require less water and drought tolerant. } \\
\text { 1-6-3 The ratio of permeable surface reaches more than } 50 \% \text {. } \\
\text { 1-6-4 Increase permeable surface each year. }\end{array}$ \\
\hline 2. Building and facilities \\
\hline 2-1 Indoor electricity saving measure. \\
\hline $\begin{array}{l}\text { 2-1-1 Adjust the utilization of electrical appliance, and set energy saving mode. } \\
\text { 2-1-2 Publish management manual for energy saving, helping energy management to audit } \\
\text { and manage. } \\
\text { 2-1-3 Concentrating in one particular place to work or have classes during holidays. } \\
\text { 2-1-4 Natural light source is the priority, to reduce unnecessary lightings. } \\
\text { 2-1-5 Milky white or light colors are selected to paint on the walls and ceiling to enhance } \\
\text { light reflection. } \\
\text { 2-1-6 Open transom windows to increase ventilation. } \\
\text { 2-1-7 Set temperature on } 28^{\circ} \mathrm{C} \text { when switching on air-conditioner and air circulated by } \\
\text { fans, air conditioners should be cleaned regularly. } \\
\text { 2-1-8 Setting energy saving mode on computers, multifunction printers, drinking fountains } \\
\text { and etc. } \\
\text { 2-1-9 Establishing power meter monitor system. } \\
\text { 2-1-10 Adapters should be located in good circulation spot or install cooling system. } \\
\text { 2-1-11 Power factor (PF) should be improved to over } 98 \% \text {. }\end{array}$ \\
\hline 2-2 Outer shell energy efficiency. \\
\hline $\begin{array}{l}\text { 2-2-1 Green walls and window blinds to help improving energy efficiency. } \\
\text { 2-2-2 Rooftop should install thermal insulation materials, high reflective paint or } \\
\text { sprinkling water. } \\
\text { 2-2-3 Install sun shading board or low emission coating on windows. } \\
\text { 2-2-4 The openings of the buildings should be equipped with sun shading or balcony. } \\
\text { 2-2-5 Set up green rooftop or green walls. }\end{array}$ \\
\hline 2-3 Water efficient facilities \\
\hline $\begin{array}{l}\text { 2-3-1Adopting water efficient faucets and toilets. } \\
\text { 2-3-2Adopting rain water recycling system, and other usage of water recycling system. } \\
\text { 2-3-3 Checking the utilization of water in campus regularly. }\end{array}$ \\
\hline 2-4 Lighting facilities. \\
\hline $\begin{array}{l}\text { 2-4-1 Adopting anti dazzle lightings and electronic stabilizers. } \\
\text { 2-4-2 Exit lights, emergency sign light, fire fighting emergency lights and other new lights } \\
\text { should be installed LED energy efficient light. } \\
\text { 2-4-3 Replace incandescent lights to high efficient light bulbs. } \\
\text { 2-4-4 Clean light fixture and light bulbs regularly. }\end{array}$ \\
\hline 3. Curriculum and teaching \\
\hline 3-1 School standard curriculum \\
\hline $\begin{array}{l}\text { 3-1-1 Planning and implementation of curriculum. } \\
\text { 3-1-2 Integrating with campus environment development course. } \\
\text { 3-1-3 Purchasing energy education related books and audio teaching materials. }\end{array}$ \\
\hline
\end{tabular}


Table 1: Continued.

\begin{tabular}{|c|}
\hline 3-2 Theme teaching activities. \\
\hline $\begin{array}{l}\text { 3-2-1 Organizing seminars, energy saving week, low carbon festivals and other theme activities. } \\
\text { 3-2-2 Promoting energy efficient products. } \\
\text { 3-2-3 Campaigning energy saving during school arts competition. } \\
\text { 3-2-4 Posting energy education activities on schools' website. }\end{array}$ \\
\hline 3-3 Incorporation into teaching course. \\
\hline $\begin{array}{l}\text { 3-3-1 Incorporation energy education into overall lesson plans. } \\
\text { 3-3-2 Teaching activities which encompass energy related planning and reforming } \\
\text { activities. } \\
\text { 3-3-3 Develop low energy handicraft education at schools. }\end{array}$ \\
\hline 4. Living and behavior \\
\hline 4-1 Energy saving actions. \\
\hline $\begin{array}{l}\text { 4-1-1 If electrical appliances are not in use for a long time, powers should be switched off, } \\
\text { or plugs should be pulled off. } \\
\text { 4-1-2 Switching off electrical appliances after work and during weekends. } \\
\text { 4-1-3 Turning off powers of computer monitors or setting sleep mode when they are not in use. } \\
\text { 4-1-4 Practice habits of turning off lights during lunch time. } \\
\text { 4-1-5 Adopt separate electric meter. }\end{array}$ \\
\hline 4-2 Water saving actions \\
\hline $\begin{array}{l}\text { 4-2-1 Reuse of wiping floor water. } \\
4-2-2 \text { Reuse of hand washing water. }\end{array}$ \\
\hline 4-3 Actions of patrol saving. \\
\hline $\begin{array}{l}\text { 4-3-1 Schools map out safe schooling pathway, encouraging walking to schools. } \\
\text { 4-3-2 Encourage students to walk, cycle or taking public transportation. } \\
\text { 4-3-3 Encourage teachers and staff to walk, cycle or taking public transportation. } \\
\text { 4-3-4 Encouraging teachers and students to take public transportation during school outings. } \\
\text { 4-3-5 Schools rent or purchase low polluted transport in priority. } \\
\text { 4-3-6 School restaurants should purchase local ingredient to reduce usage of patrol during } \\
\text { transportation. }\end{array}$ \\
\hline 4-4 Actions of reduction. \\
\hline $\begin{array}{l}\text { 4-4-1 Reduce garbage. } \\
\text { 4-4-2 Reduce kitchen waste during lunch time. } \\
\text { 4-4-3 Promote handkerchief for each person, bring one's tumbler, travel tableware kit and } \\
\text { travel lunch box to school. } \\
\text { 4-4 4-4-4 Reduce usage of paper volume, and print on both sides of the papers and recycle. } \\
\text { 4-4-5 Practice simple living to reduce carbon footprints. } \\
\text { 4-4-6 Promote low carbon diet in campus, such as drinking water campaign. }\end{array}$ \\
\hline 4-5 Green consumption \\
\hline $\begin{array}{l}\text { 4-5-1 Purchase energy efficient, low pollution, and recycled products. } \\
\text { 4-5-2 Purchase goods that stated carbon footprints. }\end{array}$ \\
\hline 5. Training and empowerment. \\
\hline 5-1 Empowerment. \\
\hline $\begin{array}{l}\text { 5-1-1 Participate in energy education training course. } \\
\text { 5-1-2 Organize teacher professional workshop. } \\
\text { 5-1-3 Forming teacher energy teaching group. }\end{array}$ \\
\hline 5-2 Introduce and integrate communities' resources. \\
\hline $\begin{array}{l}\text { 5-2-1 Cooperate with household to promote energy saving campaign. } \\
\text { 5-2-2 Practice household energy saving through communication books and energy diary, } \\
\text { and promoting energy family certification. } \\
\text { 5-2-3 Incorporate energy efficient concept into parent professional activities, to spread into } \\
\text { family and communities. } \\
\text { 5-2-4 Interaction with other schools. } \\
\text { 5-2-5 Interaction with private organizations and enterprises. } \\
\text { 5-2-6 Interaction with overseas schools or academic institute. }\end{array}$ \\
\hline
\end{tabular}




\subsection{Editing teaching materials of Taiwan Energy Education Program}

Each unit in the teacher's manual includes: The development and concept of school curriculum, basic theory of science, teaching goals, teaching time, teaching procedure, teaching evaluation (learning list) and current issues. The content includes: food mileage and carbon footprint, recycled clothing, electrical consumption, energy efficiency, comparison of transportation's consumption, solar power, wind power and water power. The teaching materials were tested in real classrooms to examine the design quality of the teaching material. Opinions from learners, designers of teaching materials, content experts will be incorporated and revised after lengthy discussions. (Figure 2)

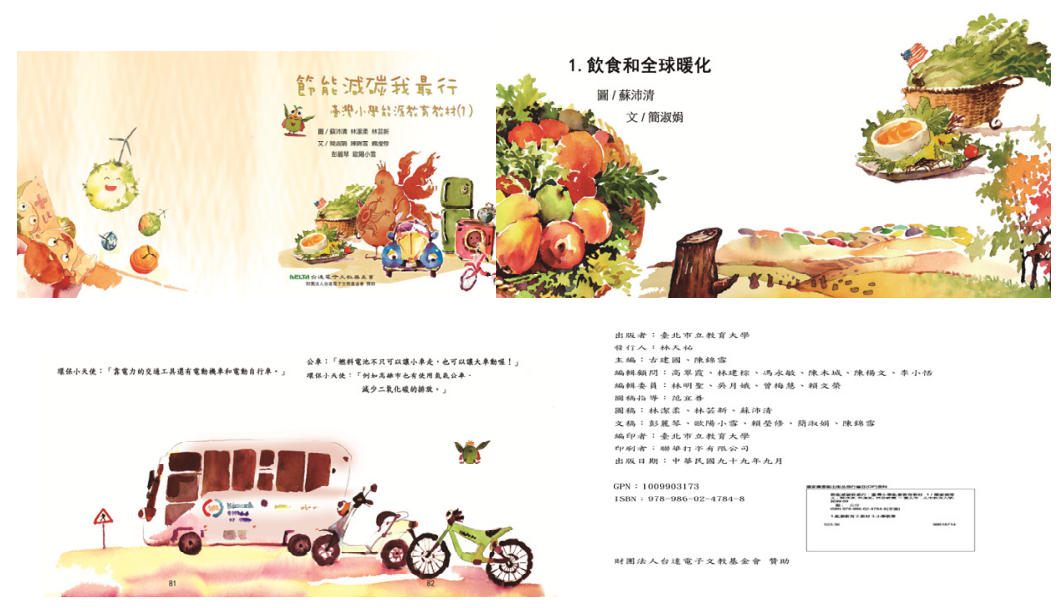

Figure 2: Images of the teaching materials.

\subsection{Conducting surveys on energy volunteer teachers' pedagogy and teaching material}

A total of 161 questionnaires were collected, among those, 20 are practical teaching feedback from teachers, 134 from elementary schools, 34 junior high schools, 52 are male, 109 are female, 60 are part time administrators, 90 are subject teachers and 9 are from other positions. The questionnaire shows that energy volunteer teachers are satisfied with the teaching and teaching material on TEEP, see Table 2.

A notable majority of volunteer teachers are satisfied with the overall seminar, regarding the arrangement and the time consumption, see Table 3.

On the aspect of motivation, school teachers hope to incorporate energy issue into lesson plans. Energy education is the new issue in recent years, most of the schools do not have such knowledge, so through counselling projects, without imposing pressure on schools, interesting teaching materials can be provided to strengthen confident of teachers toward energy education. 
Table 2: $\quad$ Satisfaction toward energy education seminar.

\begin{tabular}{|c|c|c|c|c|c|}
\hline Item & $\begin{array}{c}\text { Very } \\
\text { Satisfied }\end{array}$ & Satisfied & Accepted & $\begin{array}{c}\text { Not } \\
\text { satisfied }\end{array}$ & $\begin{array}{c}\text { Very } \\
\text { unsatisfied. }\end{array}$ \\
\hline $\begin{array}{l}\text { 1. The content of the event } \\
\text { matches my need. }\end{array}$ & $45 \%$ & $50 \%$ & $5 \%$ & 0 & 0 \\
\hline $\begin{array}{l}\text { 2. The content of the event } \\
\text { makes me feel fruitful. }\end{array}$ & $44 \%$ & $52 \%$ & $4 \%$ & 0 & 0 \\
\hline $\begin{array}{l}\text { 3. The time arrangement of } \\
\text { the lesson is appropriate. }\end{array}$ & $45 \%$ & $50 \%$ & $5 \%$ & 0 & 0 \\
\hline $\begin{array}{l}\text { 4. The content of the event is } \\
\text { helpful to the teaching, } \\
\text { classroom management or } \\
\text { administrative planning. }\end{array}$ & $36 \%$ & $57 \%$ & $7 \%$ & 0 & 0 \\
\hline $\begin{array}{l}5 . \\
\text { This event helps me to } \\
\text { deeply understand energy } \\
\text { education. }\end{array}$ & $50 \%$ & $73 \%$ & $7 \%$ & 0 & 0 \\
\hline
\end{tabular}

Table 3: $\quad$ Satisfaction toward the arrangement of the seminar.

\begin{tabular}{|c|c|c|c|c|c|}
\hline Item & $\begin{array}{c}\text { Very } \\
\text { Satisfied }\end{array}$ & Satisfied & Accepted & $\begin{array}{c}\text { Not } \\
\text { satisfied }\end{array}$ & $\begin{array}{c}\text { Very } \\
\text { unsatisfied. }\end{array}$ \\
\hline $\begin{array}{c}\text { 1.Satisfaction towards ways } \\
\text { of organizing. }\end{array}$ & $32 \%$ & $64 \%$ & $3 \%$ & 0 & 0 \\
\hline $\begin{array}{c}\text { 2.Satisfaction towards time } \\
\text { of arrangement. }\end{array}$ & $39 \%$ & $56 \%$ & $5 \%$ & 0 & 0 \\
\hline
\end{tabular}

\section{Conclusion}

This educational program intends to integrate energy management system into the daily educational operations at school. There are some successful schools cases to be carried on, and then, a new, unique and creative educational program have been developing in Taiwan. A collaboration between university (TMUE) and NGO, Delta Electronics Foundation, to promote energy education in elementary schools. TMUE plays the role of integration the curriculum experts/ professors and school teachers and edits new teaching materials for the schools, conduct surveys and develops self-evaluated indicators for participant schools, and also helping schools to work on energy planning and management. While the Foundation provides funding and expertise out of campus, like energy experts, architects and so on.

\subsection{Counselling and cultivating whole-school approach energy schools}

Altogether, five achievable themes, energy policy and management, building and facilities, curriculum and teaching, living and behavior, empowerment and improvement are in the scope of TEEP.

(1) When outlining a schedule for the future project it is advised that the project should fit in the school's schedule so that teachers can obtain the fullest benefit from the project. 
(2) The most effective way to communicate is to hold discussion with experts. It is necessary to visit energy schools once a week so that related improvement can be made.

(3) Visiting meetings to stimulate teachers to actively participate in the project so that the goal of whole-school approach can be reached.

\subsection{Energy volunteer teachers}

(1) Under TEEP, eight lessons are created for energy volunteer teachers to teach at K-12. Four lessons are related energy conservation and the other four lessons are concern with low-carbon issues.

(2) From the year 2009 to 2010,374 energy volunteer teachers participated in TEEP and served at 270 classes, and 98 schools. Approximately 11,836 students and their families gained benefit from this energy education program (Chen [16]).

\subsection{The influence of whole school approach energy school and TEEP}

The schools follow a whole-school approach, and use self-evaluation indicators as a guideline to examine energy management and education. These role models are recognized by government organizations, and even awarded by Taiwan's Ministry of Economic Affairs, Bureau of Energy. Recognizing whole-school approach Energy School and TEEP is an outstanding model to foster environmental education; Taiwan's Ministry of Education takes the effort to set up an energy education center school at each county to promote energy Education Island wide. We are looking forward to sharing these resource and methods to other schools which played as a county energy educational center, and to check the outcomes.

\section{Acknowledgement}

This research thanks Delta Electronics Foundation for their support.

\section{References}

[1] Fien, J., Heck D., Ferreira J., Learning for a Sustainable Environment: A Professional Development Guide for Teacher Educators. Brisbane, Australia: UNESCO and Griffith University, 1997.

[2] Tang, Z.-M., The Analysis of Global Sustainable Development and Schools' Green Building Planning. Education and Psychology Study, 28(3), pp.435-467, 2005.

[3] Gough, N., Blueprints for Greening Schools. Melbourne, Australia: Gould League, 1992.

[4] Wang, X., Earth Environment Education and Sustainable Development Education. Environment Education Journal, 37, pp. 87-103, 1999. 
[5] Yu, Y-H., Zhang, Y.-C., Sustainable Development Indicators, Environmental Education Journal, 37, pp.53-74, 1999.

[6] Gao, C.-X., Gao, H.-F., The Study of Environmental Education Indicator System in Taiwan Elementary Schools, Environmental Education Study, 1(2), pp.71-104, 2004.

[7] Zhang, Z.-C., The Study of Constructing Environmental Education Indicators in Government Agencies. Environmental Education Study. 4(2), pp.1-21, 2007.

[8] Lu, M.-Y., The Study of Whole-school Approach Energy School Counseling Plan and Implementation and Effectiveness of Participant Schools. Unpublished Master Dissertation, Graduate Institute of Environmental Education, National Taiwan Normal University, Taipei, 2009.

[9] Shanghai Green School, www.envir.gov.cn/educa/greenscl.html

[10] Taiwan Green School, www.greenschool.moe.edu.tw/

[11] Sustainable Campus, www.esdtaiwan.edu.tw

[12] British Ecological School, www.eco-schools.org.uk/about/

[13] The Australian Research Institute for Environment and Sustainability, www.aries.mq.edu.au/projects/whole school/files/international_review.pdf

[14] Wisconsin K12 Education Energy Program, www.uwsp.edu/cnr/wcee/keep/

[15] Delta Electronics Foundation, www.delta-foundation.org.tw/indicators.asp

[16] Chen, Y.-W., The second board meeting report of Delta Electronics Foundation at year 2010, Taipei, Taiwan, 2010 